\title{
LETTER
}

\section{Tsumebite from the Kisamori mine, Akita Prefecture, Japan}

\author{
Masayuki OHNISHI $^{*}$ and Norimasa SHIMOBAYASHI ${ }^{* *}$ \\ *80-5-103 Misasagi Bessho-cho, Yamashina-ku, Kyoto 607-8417, Japan \\ ${ }^{* *}$ Department of Geology and Mineralogy, Graduate School of Science, Kyoto University, \\ Kitashirakawa Oiwake-cho, Sakyo-ku, Kyoto 606-8502, Japan
}

\begin{abstract}
Tsumebite was discovered in a dump at the Kisamori mine, Daisen City, Akita Prefecture, northeast Japan. The mineral occurs as nodular aggregates (up to $0.5 \mathrm{~mm}$ in diameter) of platy crystals, up to $0.1 \mathrm{~mm}$ in length and $0.02 \mathrm{~mm}$ in thickness, in association with pyromorphite, quartz, limonite, and a clay mineral (potassic aluminum silicate). It is emerald green in color with a vitreous luster. The unit cell parameters obtained from the powder X-ray diffraction data are $a=7.850(2), b=5.797(1), c=8.712(2) \AA, \beta=111.92(2)^{\circ}, V=367.8(1) \AA^{3}$, and $Z=2$. Electron microprobe analyses indicate the empirical formula $\mathrm{Pb}_{2.02}\left(\mathrm{Cu}_{0.99} \mathrm{Al}_{0.01} \mathrm{Zn}_{0.01}\right)_{\Sigma 1.01}\left(\mathrm{PO}_{4}\right)_{1.01}\left(\mathrm{SO}_{4}\right)_{0.96}$ $(\mathrm{OH})_{1.12}$ on the basis of total cations $=5$ atoms per formula unit in the anhydrous part and the amount of $\mathrm{OH}$ calculated from a charge balance. The calculated density is $6.23 \mathrm{~g} / \mathrm{cm}^{3}$. It is likely that the present tsumebite was formed from a solution containing $\mathrm{Pb}, \mathrm{Cu}, \mathrm{PO}_{4}$, and $\mathrm{SO}_{4}$ ions after crystallization of pyromorphite.
\end{abstract}

Keywords: Tsumebite, Brackebuschite group, Phosphate, Sulfate, Kisamori mine, Akita

\section{INTRODUCTION}

Tsumebite, a rare basic phosphate-sulfate of lead and copper, is a member of the brackebuschite group. The general formula of this group is $A_{2} B\left(X \mathrm{O}_{4}\right)_{2} Z$, where $A$ represents a large cation such as $\mathrm{Ba}^{2+}, \mathrm{Ca}^{2+}, \mathrm{Pb}^{2+}$, or $\mathrm{Sr}^{2+} ; B$ represents $\mathrm{Al}^{3+}, \mathrm{Cu}^{2+}, \mathrm{Fe}^{2+}, \mathrm{Fe}^{3+}, \mathrm{Mn}^{2+}, \mathrm{Mn}^{3+}$, or $\mathrm{Zn}^{2+}$ in octahedral coordination; $\mathrm{XO}_{4}$ represents tetrahedral anions such as $\mathrm{AsO}_{4}^{3-}, \mathrm{CrO}_{4}^{2-}, \mathrm{PO}_{4}^{3-}, \mathrm{SO}_{4}^{2-}$, or $\mathrm{VO}_{4}^{3-}$; and $\mathrm{Z}$ represents $\mathrm{OH}^{-}$ or $\mathrm{H}_{2} \mathrm{O}$ (e.g., Fanfani and Zanazzi, 1967; Hofmeister and Tillmanns, 1978; Zubkova et al., 2002; Matsubara et al., 2004). Tsumebite was originally described by Busz (1912) from Tsumeb, Namibia (former South-West Africa). First, Busz (1912) and LaForge (1938) reported the mineral to be a hydrous phosphate of lead and copper. Subsequently, Bideaux et al. (1966) and Nichols (1966) carried out single-crystal X-ray diffraction studies of tsumebite from Morenci, Arizona, USA, and proposed a space group $P 2_{1} /$ $m$ with unit cell parameters, $a=8.70, b=5.80, c=7.85 \AA$, and $\beta=111.5^{\circ}$. Bideaux et al. (1966) and Nichols (1966) also proposed a revised ideal formula, i.e., $\mathrm{Pb}_{2} \mathrm{Cu}\left(\mathrm{PO}_{4}\right)$ $\left(\mathrm{SO}_{4}\right)(\mathrm{OH})$; however, the details of the crystal structure and chemical analyses were not provided in these literatures. Details of the structural data of tsumebite were provided by Fanfani and Zanazzi (1967). The occurrence and

doi:10.2465/jmps.090904

M. Ohnishi, czshh118a@yahoo.co.jp Corresponding author

N. Shimobayashi, shimo@kueps.kyoto-u.ac.jp chemical composition of the mineral from Broken Hill, New South Wales, Australia was described by Birch (1990) and Birch and van der Heyden (1997). Moreover, the occurrence and chemical composition of tsumebitearsentsumebite solid solution from the Roughton Gill mine, Cumbria, UK, has been documented (Tindle et al., 2006). However, a systematic description of the mineral, including both chemical analysis and X-ray diffraction data, has not yet been published.

On September 23, 2008, during a mineralogical investigation at the Kisamori mine, Japan, one of the authors (M.O.) collected a piece of quartz containing an emerald green mineral. Powder X-ray diffraction and electron microprobe analyses confirmed it to be tsumebite. This is the first discovery of tsumebite in Japan. In this paper, we report the mode of occurrence and the mineralogical properties of tsumebite obtained from the Kisamori mine.

\section{OCCURRENCE AND PHYSICAL PROPERTIES}

The Kisamori mine is located at Kyowa Funaoka, Daisen City, Akita Prefecture, northeast Japan (Lat. $39^{\circ} 40^{\prime} \mathrm{N}$, Long. $140^{\circ} 28^{\prime} \mathrm{E}$ ), but the mine is now closed. The ore deposit in this mine has a hydrothermal $\mathrm{Cu}-\mathrm{Pb}-\mathrm{Zn}$ vein running through the andesitic pyroclastic rocks in the Haginari formation of the Oligocene epoch. The vein strikes $\mathrm{N} 45^{\circ} \mathrm{E}$ and its width is $0.6 \mathrm{~m}$ (Ozawa et al., 1981). The 


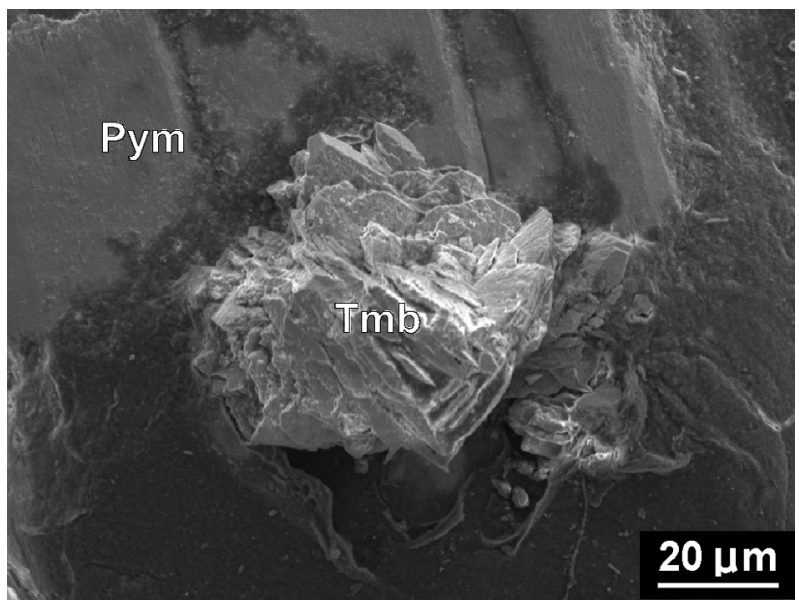

Figure 1. SE image of tsumebite from the Kisamori mine. Abbreviations: Tmb, tsumebite; Pym, pyromorphite.

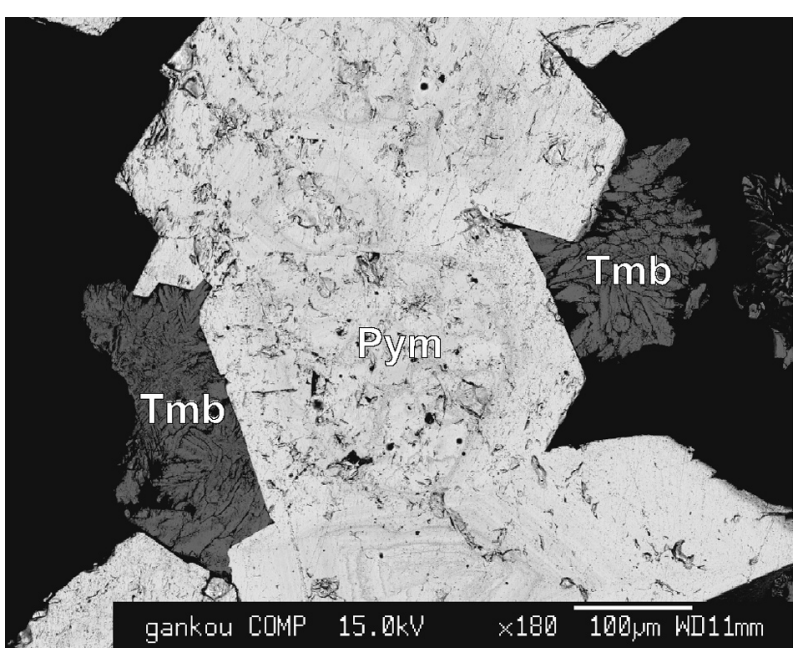

Figure 2. BSE image of tsumebite from the Kisamori mine.

ore and gangue minerals are predominantly chalcopyrite, galena, sphalerite, and quartz with lesser amounts of pyrite, hematite, chlorite, calcite, and so on. Within an oxidation zone of the ore deposit in the mine, various supergene minerals were observed, including cuprite, cerussite, malachite, brochantite, anglesite, linarite, langite, wroewolfeite, caledonite, leadhillite, lautenthalite, munakataite, beaverite, osarizawaite, hinsdalite, pyromorphite, pseudomalachite, chrysocolla, plancheite, and so on (e.g., Wada, 1904; Jimbo et al., 1916; Ito and Sakurai, 1947; Kitamine and Mouri, 1996; Matsubara et al., 1997; Yamada and Hirama, 2000).

A sample containing tsumebite was collected from a dump at the mine. The mineral rarely occurs as nodular aggregates (up to $0.5 \mathrm{~mm}$ in diameter) of platy crystals up to $0.1 \mathrm{~mm}$ in length and $0.02 \mathrm{~mm}$ in thickness on aggregates of hexagonal prismatic pyromorphite crystals (up to $2 \mathrm{~mm}$ in length and $1 \mathrm{~mm}$ in diameter). The other associ- ated minerals are quartz, limonite, and a clay mineral (potassic aluminum silicate). Secondary electron (SE) and back-scattered electron (BSE) images are shown in Figures 1 and 2, respectively. The mineral is transparent and is emerald green in color with a vitreous luster. The streak is pale green. In the thin section, pleochroism is not observed. The density, calculated using the refined unit cell parameters and the empirical formula, is $6.23 \mathrm{~g} / \mathrm{cm}^{3}$. The mineral is soluble in dilute hydrochloric acid while leaving a white residue.

\section{X-RAY DIFFRACTION}

Powder X-ray diffraction (XRD) for the present tsumebite was performed with a Rigaku RAD-1X diffractometer at Kyoto University using $\mathrm{Ni}$-filtered $\mathrm{CuK \alpha}$ radiation generated at $40 \mathrm{kV}$ and $20 \mathrm{~mA}$. The XRD data are listed in Table 1 and are compared with the XRD data of tsumebite from the Otavi mine (= Tsumeb: Anthony et al., 2000) in ICDD-PDF 29-568. The indexing of the XRD pattern was based on the brackebuschite group minerals with the space group $P 2_{1} / m$ (Fanfani and Zanazzi, 1967; Hofmeister and Tillmanns, 1978; Zubkova et al., 2002). The unit cell parameters, refined by least squares using CellCalc (Miura, 2003), are $a=7.850(2), b=5.797(1)$, $c=8.712(2) \AA, \beta=111.92(2)^{\circ}, V=367.8(1) \AA^{3}$, and $Z=$ 2 . The lengths and angle are consistent with the data in ICDD-PDF 29-568 and Nichols (1966); here, the $\boldsymbol{a}^{-}$and $\boldsymbol{c}$-axes are converted. The $\boldsymbol{b}^{-}$and $\boldsymbol{c}^{-}$axes and the angle are also smaller than those of the arsentsumebite reported by Zubkova et al. (2002) $[a=7.804(8), b=5.890(6), c=$ 8.964(8) $\AA, \beta=112.29(6)^{\circ}$, and $\left.V=381.2 \AA^{3}\right]$.

\section{INFRARED SPECTROSCOPY}

The Fourier-transform infrared-absorption (FT-IR) spectrum of the present tsumebite in the $4000 \mathrm{~cm}^{-1}$ to $400 \mathrm{~cm}^{-1}$ region was measured by the $\mathrm{KBr}$ pellet method using a JASCO MFT-680 FT-IR spectrometer at Kyoto University (Fig. 3). The broad absorption band at around 3440 $\mathrm{cm}^{-1}$ is attributed to the $\mathrm{O}-\mathrm{H}$ stretching vibration. The strong absorption bands at $1040 \mathrm{~cm}^{-1}$ and $968 \mathrm{~cm}^{-1}$ are attributed to both $v_{3}$ and $v_{1}$ stretching vibrations of both $\mathrm{PO}_{4}$ and $\mathrm{SO}_{4}$. The spectrum of tsumebite shows absorption bands at $545 \mathrm{~cm}^{-1}$ attributed to $v_{4}$ bending vibrations of $\mathrm{PO}_{4}, 473 \mathrm{~cm}^{-1}$ attributed to $v_{2}$ bending vibrations of both $\mathrm{PO}_{4}$ and $\mathrm{SO}_{4}$, and $615 \mathrm{~cm}^{-1}$ attributed to $v_{4}$ bending vibrations of both $\mathrm{PO}_{4}$ and $\mathrm{SO}_{4}$. Vibration attributed to $\mathrm{H}-\mathrm{O}-\mathrm{H}$ bending was not observed in the analysis. 
Table 1. Respective powder XRD data for tsumebite

\begin{tabular}{|c|c|c|c|c|c|c|c|c|c|c|c|c|c|c|c|}
\hline \multirow[b]{2}{*}{$h$} & \multirow[b]{2}{*}{$k$} & \multirow[b]{2}{*}{$l$} & \multicolumn{3}{|c|}{1} & \multicolumn{2}{|c|}{2} & \multirow[b]{2}{*}{$h$} & \multirow[b]{2}{*}{$k$} & \multirow[b]{2}{*}{$l$} & \multicolumn{3}{|c|}{1} & \multicolumn{2}{|c|}{2} \\
\hline & & & $d_{\text {calc. }}$ & $d_{\text {meas. }}$ & $I$ & $d$ & $I$ & & & & $d_{\text {calc. }}$ & $d_{\text {meas. }}$ & $I$ & $d$ & $I$ \\
\hline 0 & 0 & 1 & 8.08 & 8.11 & 8 & 8.04 & 8 & $\overline{1}$ & 1 & 4 & 2.029 & 2.029 & 25 & 2.025 & 11 \\
\hline & & & & & & 5.22 & 5 & $\underline{3}$ & 1 & 1 & 1.989 & 1.990 & 4 & 1.992 & 11 \\
\hline 0 & 1 & 1 & 4.71 & 4.72 & 31 & 4.70 & 30 & $\underline{2}$ & 2 & 3 & 1.976 & 1.977 & 6 & 1.971 & 7 \\
\hline 1 & 0 & 1 & 4.62 & 4.63 & 4 & 4.62 & 8 & $\underline{\overline{4}}$ & 0 & 2 & 1.956 & 1.954 & 4 & 1.958 & 8 \\
\hline 1 & 1 & 0 & 4.54 & & & 4.53 & 3 & $\underline{3}$ & 0 & 4 & 1.952 & דתנ. & & & \\
\hline$\frac{1}{-}$ & 1 & 1 & 4.42 & 4.42 & 6 & 4.40 & 7 & $\underline{4}$ & 0 & 3 & 1.866 & 1.866 & 10 & 1.868 & 9 \\
\hline$\overline{1}$ & 0 & 2 & 4.27 & 4.28 & 6 & 4.28 & 6 & $\underline{4}$ & 1 & 2 & 1.853 & 1851 & 35 & 1847 & 20 \\
\hline$\underline{0}$ & 0 & 2 & 4.04 & 4.05 & 8 & 4.04 & 8 & $\overline{3}$ & 1 & 4 & 1.850 & $1.0 \mathrm{~J}$ & נJ & 1.047 & 20 \\
\hline$\overline{2}$ & 0 & 1 & 3.912 & 3.916 & 11 & 3.92 & 20 & 4 & 0 & 0 & 1.821 & & & 1.825 & 8 \\
\hline 2 & 0 & 0 & 3.641 & 3.639 & 9 & 3.65 & 15 & 3 & 2 & 3 & 1.789 & 1.789 & 11 & 1.785 & 11 \\
\hline$\frac{1}{2}$ & 1 & 1 & 3.613 & 3.617 & 17 & 3.61 & 15 & 2 & 3 & 1 & 1.733 & 1.733 & 6 & 1.730 & 8 \\
\hline$\underline{1}$ & 1 & 2 & 3.441 & 3.442 & 8 & 3.43 & 12 & 3 & 2 & 1 & 1.710 & & & 1.710 & 8 \\
\hline 2 & 0 & 2 & 3.412 & 3.416 & 18 & 3.41 & 14 & $\underline{2}$ & 3 & 0 & 1.707 & 1.706 & 8 & 1.704 & 8 \\
\hline$\underline{0}$ & 1 & 2 & 3.315 & 3.316 & 13 & 3.31 & 12 & $\underline{4}$ & 0 & 4 & 1.706 & & & & \\
\hline 2 & 1 & 1 & 3.243 & 3.246 & 100 & 3.24 & 100 & $\overline{3}$ & 0 & 5 & 1.662 & 1.662 & 7 & 1.659 & 5 \\
\hline$\underline{2}$ & 1 & 0 & 3.084 & 3.082 & 11 & 3.08 & 18 & $\frac{1}{1}$ & 3 & 2 & 1.637 & 1.637 & 6 & & \\
\hline$\underline{2}$ & 1 & 2 & 2.940 & 2.943 & 31 & 2.936 & 35 & $\underline{4}$ & 1 & 4 & 1.636 & 1.007 & & & \\
\hline 1 & 0 & 3 & 2.904 & 2.905 & 97 & 2.897 & 65 & 4 & 2 & 2 & 1.621 & 1.622 & 6 & & \\
\hline$\underline{1}$ & 1 & 2 & 2.719 & 2.721 & 36 & 2.718 & 35 & 2 & 3 & 1 & 1.614 & 1.614 & 4 & & \\
\hline$\overline{2}$ & 0 & 3 & 2.701 & 2.698 & 9 & 2.691 & 8 & 3 & 1 & 5 & 1.597 & 1.597 & 4 & & \\
\hline 1 & 2 & 1 & 2.668 & 2.669 & 3 & 2.665 & 3 & 5 & 0 & 3 & 1.545 & 1.545 & 3 & & \\
\hline$\underline{2}$ & 1 & 1 & 2.618 & 2.620 & 11 & 2.619 & 25 & $\underline{4}$ & 2 & 0 & 1.542 & 1.542 & 3 & & \\
\hline 1 & 1 & 3 & 2.596 & 2.597 & 4 & 2.590 & 3 & 3 & 3 & 2 & 1.538 & 1.537 & 3 & & \\
\hline$\underline{3}$ & 0 & 2 & 2.542 & & & 2.543 & 5 & $\underline{5}$ & 0 & 1 & 1.537 & & & & \\
\hline 2 & 1 & 3 & 2.448 & 2.448 & 7 & & & 1 & 2 & 5 & 1.479 & 1.478 & 4 & & \\
\hline$\underline{3}$ & 0 & 0 & 2.428 & 2.428 & 4 & 2.432 & 8 & 2 & 0 & 6 & 1.452 & 1.452 & 4 & & \\
\hline 1 & 2 & 2 & 2.399 & 2.400 & 5 & 2.395 & 5 & 3 & 3 & 1 & 1.427 & 1.427 & 4 & & \\
\hline$\underline{2}$ & 2 & 0 & 2.268 & 2.268 & 38 & 2.267 & 35 & $\underline{0}$ & 4 & 1 & 1.427 & 1.72 & 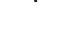 & & \\
\hline$\underline{2}$ & 2 & 2 & 2.209 & 2.210 & 5 & & & $\underline{5}$ & 1 & 4 & 1.425 & 1.425 & 4 & & \\
\hline$\overline{2}$ & 0 & 4 & 2.137 & 2.138 & 4 & & & $\overline{3}$ & 0 & 6 & 1.425 & 10.20 & & & \\
\hline 1 & 1 & 3 & 2.111 & 2.111 & 4 & & & $\frac{4}{-}$ & 3 & 2 & 1.375 & 1.374 & 4 & & \\
\hline$\underline{1}$ & 2 & 2 & 2.111 & & & & & 3 & 3 & 4 & 1.373 & & & & \\
\hline 1 & 2 & 3 & 2.052 & 2.051 & 13 & 2.046 & 14 & & & & & & & & \\
\hline
\end{tabular}

1. Kisamori mine, Japan: $a=7.850(2), b=5.797(1), c=8.712(2) \AA, \beta=111.92(2)^{\circ}$, and $V=367.8(1) \AA^{3}$ (present work).

2. Tsumeb, Namibia (ICDD-PDF 29-568).

\section{CHEMICAL COMPOSITION}

Chemical analyses of the present tsumebite were carried out using a JEOL JXA-8105 electron microprobe analyzer at Kyoto University with a wavelength-dispersive spectrometry (WDS). Preliminary qualitative analyses indicated that the mineral consisted of $\mathrm{Pb}, \mathrm{Cu}, \mathrm{P}, \mathrm{S}$, and small amounts of Al and Zn. The BSE image (Fig. 2) did not show compositional zoning or intergrowths. Quantitative analyses were performed at an accelerating voltage of 15 $\mathrm{kV}$, beam current of $10 \mathrm{nA}$, and beam diameter of $3 \mu \mathrm{m}$. The standard materials employed were crocoite $(\mathrm{Pb} L \alpha)$, cuprite $(\mathrm{Cu} K \alpha)$, synthetic yttrium aluminum garnet $(\mathrm{AlK \alpha})$, sphalerite $(\mathrm{ZnK \alpha}$ and $\mathrm{S} K \alpha)$, and apatite- $(\mathrm{CaF})$ $(\mathrm{P} K \alpha)$. All the data were corrected with the Bence and Albee (1968) method. The $\mathrm{H}_{2} \mathrm{O}$ content was calculated for charge balance as $\mathrm{OH}$, as confirmed by FT-IR spectroscopy (Fig. 3), because of the lack of available samples. The results of the WDS analyses of the minerals are listed in Table 2 and are compared with the theoretical values of $\mathrm{Pb}_{2} \mathrm{Cu}\left(\mathrm{PO}_{4}\right)\left(\mathrm{SO}_{4}\right)(\mathrm{OH})$ and the values provided by Busz (1912), LaForge (1938), Birch (1990), and Tindle et al. (2006). The empirical formula of tsumebite obtained from the Kisamori mine, which is calculated on the basis of to- 


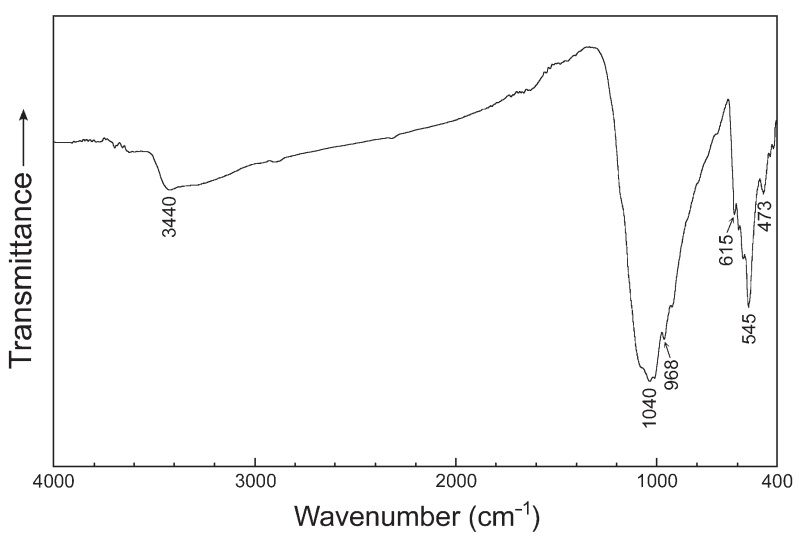

Figure 3. FT-IR spectrum of tsumebite from the Kisamori mine.

tal cations $=5$ atoms per formula unit (apfu) in the anhydrous part, is $\mathrm{Pb}_{2.02}\left(\mathrm{Cu}_{0.99} \mathrm{Al}_{0.01} \mathrm{Zn}_{0.01}\right)_{\Sigma 1.01}\left(\mathrm{PO}_{4}\right)_{1.01}\left(\mathrm{SO}_{4}\right)_{0.96}$ $(\mathrm{OH})_{1.12}$.

\section{DISCUSSION}

The ideal chemical formula of tsumebite, $\mathrm{Pb}_{2} \mathrm{Cu}\left(\mathrm{PO}_{4}\right)$ $\left(\mathrm{SO}_{4}\right)(\mathrm{OH})$, was first proposed by Nichols (1966). The chemical analyses of tsumebite from Tsumeb reported by both Busz (1912) and LaForge (1938) are incorrect; they missed the presence of $\mathrm{SO}_{3}$ and considered excess $\mathrm{H}_{2} \mathrm{O}$ instead (Table 2). The chemical composition of the present tsumebite from the Kisamori mine is close to the ideal formula reported by Nichols (1966), and only small amounts of $\mathrm{Al}$ and $\mathrm{Zn}$ substitute $\mathrm{Cu}$. As shown in Figure 4, the chemical composition of the sulfate-bearing brackebuschite group minerals is plotted on a ternary $\left(\mathrm{SO}_{4}\right)_{2}{ }^{-}$ $\left(\mathrm{PO}_{4}\right)_{2}-\left(\mathrm{AsO}_{4}\right)_{2}$ diagram. The present tsumebite is also free of As and V, and the $2 \times \mathrm{S} /(\mathrm{P}+\mathrm{S})$ value is 0.98 $(0.88-1.08)$. This ratio is similar to the $2 \times \mathrm{S} /(\mathrm{P}+\mathrm{As}+\mathrm{S})$ value of $1.00(0.88-1.07)$ for tsumebite-arsentsumebite solid solution from the Roughton Gill mine (Tindle et al., 2006), and it is higher than the following values men-

Table 2. Chemical composition of tsumebite

\begin{tabular}{|c|c|c|c|c|c|c|c|c|}
\hline & \multicolumn{3}{|c|}{$1\left(n^{*}=5\right)$} & \multirow{2}{*}{2} & \multirow{2}{*}{3} & \multirow{2}{*}{4} & \multirow{2}{*}{5} & \multirow{2}{*}{6} \\
\hline & Average & Range & $\sigma^{* *}$ & & & & & \\
\hline \multicolumn{9}{|l|}{$\mathrm{wt} \%$} \\
\hline $\mathrm{PbO}$ & 66.15 & $65.78-66.51$ & 0.27 & 65.07 & 64.97 & 62.1 & 63.77 & 64.71 \\
\hline $\mathrm{CuO}$ & 11.55 & $11.18-11.84$ & 0.30 & 11.60 & 11.35 & 11.0 & 11.79 & 12.13 \\
\hline $\mathrm{ZnO}$ & 0.09 & $0.00-0.21$ & 0.09 & & 0.07 & & & \\
\hline $\mathrm{Al}_{2} \mathrm{O}_{3}$ & 0.10 & $0.04-0.24$ & 0.08 & & & & & \\
\hline $\mathrm{P}_{2} \mathrm{O}_{5}$ & 10.52 & $10.11-10.89$ & 0.35 & 10.35 & 10.27 & 6.8 & 12.01 & 10.62 \\
\hline $\mathrm{As}_{2} \mathrm{O}_{5}$ & & & & & & 5.0 & & \\
\hline $\mathrm{SO}_{3}$ & 11.31 & $10.94-11.64$ & 0.28 & 11.67 & 8.96 & 11.1 & & \\
\hline $\mathrm{H}_{2} \mathrm{O}$ & $1.48^{* * *}$ & & & 1.31 & & & 12.33 & 12.09 \\
\hline Total & 101.20 & & & 100.00 & 95.62 & 96.0 & 99.90 & $100.33^{* * * *}$ \\
\hline \multicolumn{9}{|c|}{ Total cations $=5$ apfu (anhydrous part) } \\
\hline $\mathrm{Pb}$ & 2.02 & $2.00-2.04$ & 0.01 & 2.00 & 2.11 & 2.00 & & \\
\hline $\mathrm{Cu}$ & 0.99 & $0.97-1.01$ & 0.03 & 1.00 & 1.03 & 1.00 & & \\
\hline $\mathrm{Zn}$ & 0.01 & $0.00-0.02$ & 0.03 & & 0.01 & & & \\
\hline $\mathrm{Al}$ & 0.01 & $0.01-0.03$ & 0.02 & & & & & \\
\hline $\mathrm{P}$ & 1.01 & $0.98-1.04$ & 0.01 & 1.00 & 1.05 & 0.69 & & \\
\hline As & & & & & & 0.31 & & \\
\hline S & 0.96 & $0.92-0.99$ & 0.02 & 1.00 & 0.81 & 1.00 & & \\
\hline $\mathrm{H}$ & 1.12 & & & 1.00 & & & & \\
\hline $\mathrm{Cu} /(\mathrm{Cu}+\mathrm{Zn}+\mathrm{Al})$ & 0.98 & $0.96-1.00$ & 0.01 & 1.00 & 0.99 & 1.00 & & \\
\hline $\mathrm{P} /(\mathrm{P}+\mathrm{As})$ & 1.00 & & & 1.00 & 1.00 & 0.69 & & \\
\hline $\mathrm{S} /(\mathrm{P}+\mathrm{As}+\mathrm{S})$ & 0.49 & $0.44-0.54$ & 0.02 & 0.50 & 0.44 & 0.50 & & \\
\hline
\end{tabular}

1. Kisamori mine, Japan (present work).

2. Theoretical values of $\mathrm{Pb}_{2} \mathrm{Cu}\left(\mathrm{PO}_{4}\right)\left(\mathrm{SO}_{4}\right)(\mathrm{OH})$.

3. Broken Hill, Australia (Birch, 1990).

4. Roughton Gill mine, UK (Tindle et al., 2006). The values are average of 24 WDS analyses.

5. Tsumeb, Namibia (Busz, 1912).

6. Tsumeb, Namibia (LaForge, 1938); The analysis includes $\mathrm{ZnO} 0.54$ and $\mathrm{CO}_{2} 0.24$ as smithsonite impurities.

*Analyzed spots; ${ }^{* *}$ Standard deviation; ${ }^{* * *}$ Obtained by charge balance calculation; ${ }^{* * * *}$ Oxide total of 99.79 in the reference is an error for 100.33 . 


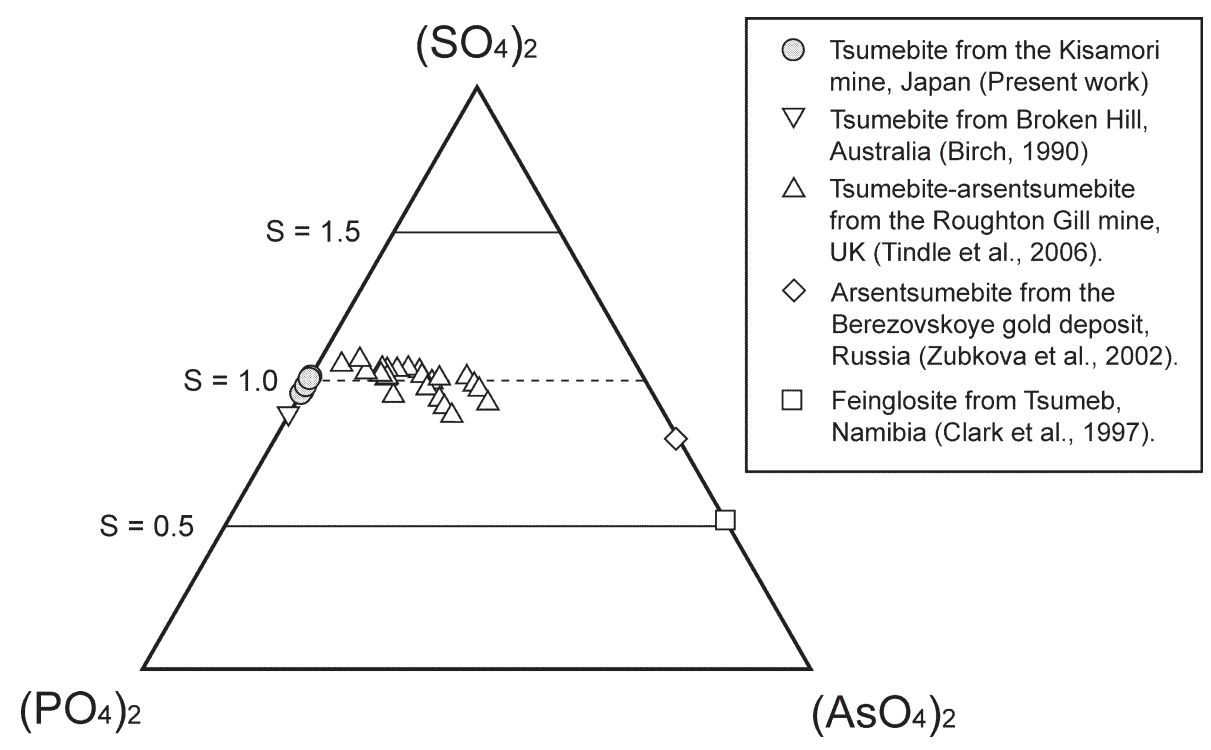

Figure 4. Ternary $\left(\mathrm{SO}_{4}\right)_{2}-\left(\mathrm{PO}_{4}\right)_{2}-\left(\mathrm{AsO}_{4}\right)_{2}$ diagram of the $\mathrm{XO}_{4}$ site in the sulfate-bearing brackebuschite group minerals. tioned in the literature for sulfate-bearing brackebuschite group minerals: 0.88 for tsumebite from Broken Hill (Birch, 1990); 0.78 for arsentsumebite from the Berezovskoye gold deposit, Middle Urals, Russia (Zubkova et al., 2002); and 0.52 for feinglosite from Tsumeb (Clark et al., 1997). The sulfate-bearing vanadate member of the brackebuschite group minerals has not been reported. According to structural studies (Fanfani and Zanazzi, 1967; Hofmeister and Tillmanns, 1978; Zubkova et al., 2002), the brackebuschite group minerals have two independent distinct $\mathrm{XO}_{4}$ tetrahedral sites. Fanfani and Zanazzi (1967) noted that $\mathrm{SO}_{4}$ has ordered distribution in the one of the tetrahedral sites, but Zubkova et al. (2002) showed that $\mathrm{SO}_{4}$ has disordered distribution in both the tetrahedral sites. Therefore, the empirical formula of the present tsumebite might be $\mathrm{Pb}_{2.02}\left(\mathrm{Cu}_{0.99} \mathrm{Al}_{0.01} \mathrm{Zn}_{0.01}\right)_{\Sigma 1.01}\left[\left(\mathrm{P}_{0.50} \mathrm{~S}_{0.48}\right)_{\Sigma 0.98} \mathrm{O}_{4}\right]_{2}$ $(\mathrm{OH})_{1.12}$. It should be noted that the anions occupying the tetrahedral sites of the present tsumebite are only $\mathrm{PO}_{4}$ and $\mathrm{SO}_{4}$, and the ratio is close to $1: 1$.

The present tsumebite occurs as aggregates of platy crystals in association with pyromorphite, quartz, limonite, and the clay mineral. The associated pyromorphite is close to the ideal composition, $\mathrm{Pb}_{5}\left(\mathrm{PO}_{4}\right)_{3} \mathrm{Cl}$; the WDS analyses $(\mathrm{n}=4)$ indicate an empirical formula of $\mathrm{Pb}_{4.98}$ $\left(\mathrm{PO}_{4}\right)_{3.04} \mathrm{Cl}_{0.98}$ on the basis of total atoms $=9 \mathrm{apfu}$. The aggregates of tsumebite crystals occur in direct contact with euhedral crystals of pyromorphite and quartz, and the boundary between tsumebite and pyromorphite is sharply defined (Fig. 2). The mode of occurrence indicates that the present tsumebite was formed from a solution containing $\mathrm{Pb}, \mathrm{Cu}, \mathrm{PO}_{4}$, and $\mathrm{SO}_{4}$ ions post pyromorphite crystallization. Matsubara et al. (1997) reported that hinsdalite, a phosphate-sulfate of lead and aluminum, found in the Kisamori mine was formed as a product of the reaction between $\mathrm{SO}_{4}$ and pyromorphite. The phosphate-sulfate (hinsdalite) is a compositional intermediate between phosphate (pyromorphite) and sulfate (beaverite-osarizawaite solid solution). The order of phosphate and sulfate mineralization in the study sample is similar to that of the hinsdalite reported by Matsubara et al. (1997). However, the origins of the two minerals are different. Matsubara and Matsuyama (1997) reported that the sulfate-bearing arsenate minerals such as segnitite and philipsbornite from the Tohgane mine, Gifu Prefecture, Japan formed as a product of the reaction between $\mathrm{SO}_{4}$ and an arsenate mineral such as scorodite. The respective geneses of phosphate-sulfate and arsenate-sulfate share a commonality.

\section{ACKNOWLEDGMENTS}

We are grateful to Drs. Hideki Murakami and Chiyoko Henmi for their constructive and critical reviews of this manuscript.

\section{REFERENCES}

Anthony, J.W., Bideaux, R.A., Bladh, K.W. and Nichols, M.C. (2000) Handbook of Mineralogy. Vol. IV. pp. 680, Mineral Data Publishing, Tucson, USA.

Bence, A.E. and Albee, A.L. (1968) Empirical correction factors for the electron microanalysis of silicates and oxides. Journal of Geology, 76, 382-403.

Bideaux, R.A., Nichols, M.C. and Williams, S.A. (1966) The arsenate analog of tsumebite, a new mineral (Abstract of papers, Mineralogical Society of America Joint Meeting with the American Crystallographic Association, June 27-July 2, 1965). American Mineralogist, 51, 258-259.

Birch, W.D. (1990) Minerals from Kintore and Block 14 opencuts, Broken Hill, N.S.W.; review of recent discoveries, including 
tsumebite, kipushite and otavite. Australian Mineralogist, 5, 125-141.

Birch, W.D. and van der Heyden, A. (1997) Minerals of the Kintore and Block 14 open cuts at Broken Hill, New South Wales. Australian Journal of Mineralogy, 3, 23-71.

Busz, K. (1912) Tsumebit, ein neues Blei-Kupfer-Phosphat von Otavi, Deutsch Süd-West-Afrika. Deutscher Naturforscher und Årzte in Münster, Versammlung, 84, 162-165 (in German).

Clark, A.M., Criddle, A.J., Roberts, A.C., Bonardi, M. and Moffatt, E.A. (1997) Feinglosite, a new mineral related to brackebuschite, from Tsumeb, Namibia. Mineralogical Magazine, 61, 285-289.

Fanfani, L. and Zanazzi, P.F. (1967) Structural similarities of some secondary lead minerals. Mineralogical Magazine, 36, 522529.

Hofmeister, W. and Tillmanns, E. (1978) Structural investigation of arsenbrackebuschite. Tschermaks Mineralogishe und Petrographische Metteilungen, 25, 153-163 (in German with English abstract).

Ito, T. and Sakurai, K. (1947) Wada's minerals of Japan, Ed. 3rd. pp. 368, Chubunkan-shoten, Tokyo, Japan (in Japanese).

Jimbo, K., Takimoto, T. and Fukuchi, N. (1916) Wada's minerals of Japan, Ed. 2nd. pp. 392, Shuei-sha, Tokyo, Japan (in Japanese).

Kitamine, M. and Mouri, T. (1996) Caledonite from Kisamori mine, Akita Prefecture. Chigaku Kenkyu, 45, 195-198 (in Japanese).

LaForge, L. (1938) Crystallography of tsumebite. American Mineralogist, 23, 772-782.

Matsubara, S. and Matsuyama, F. (1997) Segnitite from the Tohgane mine, Gifu Prefecture, Japan. Journal of the Mineralogical Society of Japan, 26, 181-184 (in Japanese with English abstract).

Matsubara, S., Tiba, T., Kato, A. and Matsuyama, F. (1997) Hinsdalite from the Kobetsuzawa mine, Hokkaido and the Kisamori mine, Akita Prefecture, Japan. Abstracts with Pro- gram, 1997 Fall Meeting of the Japanese Association of Mineralogist, Petrologist and Economic Geologist, Sptember, 1997, 159.

Matsubara, S., Miyawaki, R., Yokoyama, K., Shimizu, M. and Imai, H. (2004) Tokyoite, $\mathrm{Ba}_{2} \mathrm{Mn}^{3+}\left(\mathrm{VO}_{4}\right)_{2}(\mathrm{OH})$, a new mineral from the Shiromaru mine, Okutama, Tokyo, Japan. Journal of Mineralogical and Petrological Sciences, 99, 363-367.

Miura, H. (2003) CellCalc: A unit cell parameter refinement program on Windows computer. Journal of the Crystallographic Society of Japan, 45, 145-147 (in Japanese).

Nichols, M.C. (1966) The crystal structure of tsumebite (Abstract of papers, the Mineralogical Society of America Joint Meeting with the American Crystallographic Association, June 27-July 2, 1965). American Mineralogist, 51, 267.

Ozawa, A., Kano, H., Maruyama, T., Tsuchiya, N., Ito, M., Hirayama, J. and Shinada, S. (1981) Geology of the Taiheizan district. With Geological Sheet Map at 1:50,000, Geological Survey of Japan (in Japanese with English abstract).

Tindle, A.G., Bridges, T.F. and Green, D.I. (2006) The composition of tsumebite from Roughton Gill mine, Caldbeck Fells, Cumbria. UK Journal of Mines \& Minerals, 27, 48-50.

Wada, T. (1904) Minerals of Japan. pp. 281, Tokyo, Japan (in Japanese).

Yamada, T. and Hirama, T. (2000) Two new minerals for Japan from Kisamori mine, Akita prefecture; wroewolfeite and lautenthalite. Quartz (Journal of Friends of Minerals, Tokyo), 13, 21-25 (in Japanese).

Zubkova, N.V., Pushcharovsky, D.Y., Giester, G., Tillmanns, E., Pekov, I.V. and Kleimenov, D.A. (2002) The crystal structure of arsentsumebite, $\mathrm{Pb}_{2} \mathrm{Cu}\left[(\mathrm{As}, \mathrm{S}) \mathrm{O}_{4}\right]_{2}(\mathrm{OH})$. Mineralogy and Petrology, 75, 79-88.

Manuscript received September 4, 2009

Manuscript accepted April 13, 2010

Published online May 28, 2010

Manuscript handled by Motoharu Kawano 